\title{
Analisa Perbandingan Agregat Kasar Yang Berasal Dari Sungai Dan Gunung Terhadap Kuat Tekan Dan Kuat Tarik Belah Beton
}

\section{Coarse Aggregate Comparative Analysis Coming From River And Mountain Against Strong Press And Strength Concrete Drag}

\author{
Armin Naibaho ${ }^{\mathrm{a}}$ \\ a Jurusan Teknik Sipil Politeknik Negeri Malang, email: ar_naibaho@yahoo.co.id
}

\begin{abstract}
ABSTRAK
Salah satu cara untuk meningkatkan kekuatan beton adalah memilih jenis agregat kasar yang tepat. Penelitian ini bertujuan mengetahui perbandingan kualitas agregat kasar dari batu gunung dan dari batu sungai terhadapkuat tekan beton fc' $30 \mathrm{MPa}$ (K300)dan kuat tarik belah beton.

Penelitian ini menggunakan agregat kasar dari batu gunung dengan warna abu-abu dan berdebu yang diperoleh dari Desa Beji Kec. Junrejo Kota Batu sedangkan agregat kasar dari batu sungai berwarna lebih gelap dan bersih berasal dari Sungai Brantas Kab. Malang dengan ukuran masing-masing maksimal $40 \mathrm{~mm}$.

Penelitian ini dilakukan di laboratorium bahan bangunan dan beton Politeknik Negeri - Malang, dan pelaksaannya dimulai pada tanggal 29 Juli sampai 30 Agustus 2016. Pada pengujian kuat tekan beton menggunakan 10 benda uji sama dengan pengujian kuat tarik belah beton juga menggunakan 10 benda uji, masing-masing terdiri dari 5 sampel agregat kasar daribatu sungai dan 5 sampeldaribatu gunung. Pengujian kuat tekan beton menggunakan benda uji kubus ( $150 \times 150 \times 150 \mathrm{~mm})$,pengujian kuat tarik belah beton menggunakan benda uji bentuk silinder (diameter $150 \mathrm{~mm}$ dan tinggi $30 \mathrm{~mm}$ ). Seluruh prosedur pengujian, analisis hasil pengujian dan penarikan kesimpulan penelitian ini menggunakan SNI.

Hasil uji kuat tekan beton menggunakan agregat kasar dari batu gunung $615,38 \mathrm{~kg} / \mathrm{cm} 2 \mathrm{masuk}$ fc' $30 \mathrm{MPa}$ (K600) sehingga lebih besar dari batu sungai $587,35 \mathrm{~kg} / \mathrm{cm} 2$ masuk fc' $50 \mathrm{Mpa}$ (K500). Hasil pengujian kuat tarik belah beton menggunakan agregat kasar dari batu gunung $29,6 \mathrm{~kg} / \mathrm{cm} 2$ lebih kecil dari batu sungai $35,5 \mathrm{~kg} / \mathrm{cm} 2$.Keduanya sama-sama kurang dari $10 \%$ terhadap kuat tekannya.

Hasil uji kuat tekan beton yang menggunakan agregat kasar dari batu gunung lebih baik dari batu sungai,karenamudah homogen dan takaran air sisa 0,7 liter, sehingga nilai slump lebih rendah. Sedangkan nilai kuat tarik belah beton menggunakan agregat kasar dari batu sungai lebih tinggi dari batu gunung karena termasuk jenis batuan vulkanik yang memiliki pori lebih kecil sedangkan batu gunung termasuk batuanendapanyang tersingkap di dalam tanah.

Kesimpulannya, penggunaan kedua agregat kasar tersebut layak digunakan sebagai material bangunan pada rencana beton fc' $30 \mathrm{Mpa}$ (K300) dengan menggunakan mix desain SNI untuk RAB. Tetapi perlu diteliti kembali dengan proporsi campuran yang sama yang menggunakan mix design SNI 03-2834-1993.
\end{abstract}

Kata-kata kunci: agregatkasar, sungai, gunung, kuat tekan, kuat tarik belah, beton. 


\section{PENDAHULUAN}

Dengan banyaknya penggunaan beton sebagai material konstruksi, penulis semakin ingin mengetahui bagaimana perbandingan kualitas agregat kasar yang berasal dari Sungai Brantas Kabupaten Malang daripada batu gunung di Desa Beji Kec. Junrejo Kota Batu terhadap kuat tekan dan kuat tarik belah beton. Karena sifat kekuatan beton tersebut akan berpengaruh terhadap kekuatan suatu struktur. Semakin besar kekuatan beton semakin besar pula kekuatan struktur tersebut. Berdasarkan uraian diatas maka penulis ingin mengetahui analisa perbandingan agregat kasar yang berasal dari sungai dan gunung terhadap kuat tekan dan kuat tarik belah beton. Sehingga kita dapat mengetahui manfaatnya baik secara teori maupun penerapan waktu berada di lapangan.

Jenis batuan yang digunakan dalam penelitian ini adalah dari gunung jenis batu endapan karena berbentuk bongkahan dan berpasir, jenis kedua dari sungai termasuk batu vulkanik karena bentuknya bulat dan gelap.

\section{KAJIAN PUSTAKA}

\section{A. Pengujian Kualitas Agregat Kasar \\ 1. Berat Jenis Agregat Kasar}

Nugraha (2007:55) menjelaskan, berat jenis agregat adalah 2400-2900 kg/m3. Berat jenis ini agak sukar untuk diukur karena agregat mempunyai pori. Namun untungnya juga jarang diperlukan. Yang lebih diperlukan adalah berat volume kering. Berat volume kering agregat adalah sekitar $1200-1750 \mathrm{~kg} / \mathrm{m} 3$.

\section{Penyerapan Air Agregat}

Penyerapan air menurut SNI, yaitu perbandingan berat air yang dapat diserap pori terhadap berat agregat kering (\%) atau penambahan berat dari suatu agregat akibat air yang meresap ke dalam pori-pori, tetapi belum termasuk air yang tertahan pada permukaan luar partikel, dinyatakan sebagai persentase dari berat keringnya; agregat dikatakan "kering" ketika telah dijaga pada suatu temperatur $\left(110^{\circ} \mathrm{C} \pm 5^{\circ} \mathrm{C}\right)$ dalam rentang waktu yang cukup untuk menghilangkan seluruh kandungan air yang ada (sampai beratnya tetap).

Penyerapan air agregat halus penelitian ini dari Pasir Lumajang mempunyai penyerapan air 5,263\% (Safrin Zuraidah \& Rahmat Arif Jatmiko:2007).

\section{Kadar Air Agregat Kasar}

Nugraha (2007:56) menjelaskan air yang terkandung di dalam agregat akan mempengaruhi jumlah air yang diperlukan di dalam campuran (mix). Agregat yang basah akan membuat campuran lebih basah dan meningkatkan faktor air semen, dan sebaliknya agregat yang kering akan menyerap air campuran dan menurunkan kelecakan beton. Jadi kandungan air di dalam agregat harus diketahui.

\section{Gradasi Agregat Normal}

Gradasi ialah distribusi (pembagian) ukuran butir agregat. Agregat diayak berurutan menurut ayakan standar yang disusun mulai dari ayakan terbesar di bagian paling atas. Agregat diletakkan di bagian atas tersebut. Setelah digetarkan cukup lama, berat agregat 
yang tertahan pada setiap ayakan dicatat, dihitung prosesntasenya. Persentase kumulatif tertahan dan persentase kumulatif lolos kemudian dihitung. (Nugraha, 2007:44).

Tabel batas gradasi agregat halus

\begin{tabular}{|c|c|}
\hline $\begin{array}{c}\text { Lubang } \\
\text { ayakan } \\
(\mathrm{mm})\end{array}$ & $\begin{array}{c}\text { Persentase berat butir yang lewat } \\
\text { ayakan }\end{array}$ \\
\cline { 2 - 2 } & $\mathrm{I}$ \\
\hline 10 & 100 \\
\hline 4.8 & $90-100$ \\
\hline 2.4 & $60-95$ \\
\hline 1.2 & $30-70$ \\
\hline 0.6 & $15-34$ \\
\hline 0.3 & $5-20$ \\
\hline 0.15 & $0-10$ \\
\hline
\end{tabular}

(Mulyono, 2005:91)

Tabel syarat agregat kasar

\begin{tabular}{|c|c|}
\hline $\begin{array}{c}\text { Lubang } \\
\text { ayakan }(\mathrm{mm})\end{array}$ & $\begin{array}{c}\text { Persen butir lewat ayakan, besar } \\
\text { maks }\end{array}$ \\
\cline { 2 - 3 } & $40 \mathrm{~mm}$ \\
\hline 40 & $95-100$ \\
\hline 20 & $30-70$ \\
\hline 12.5 & - \\
\hline 10 & $10-35$ \\
\hline 4.8 & $0-5$ \\
\hline \multicolumn{2}{|c|}{ (Mulyono, 2005:94) }
\end{tabular}

\section{B. Standar Penilaian Beton}

\section{Tata Cara Perhitungan Proporsi Campuran Beton}

Berikut ini langkah-langkah perhitungan proporsi campuran beton :

a. Kuat tekan rata-rata yang ditargetkan

b. Deviasi standar yang didapat dari pengalaman di lapangan selama produksi beton.

c. Pemilihan Faktor Air Semen

d. Nilai tambah dihitung menurut rumus : $\mathrm{M}=1,64 \mathrm{x} \mathrm{Sr}$

e. Kuat tekan rata-rata yang ditargetkan dihitung menurut rumus berikut :

f. Slump Beton

g. Besar Butir Agregat Maksimum

\section{Kuat Tekan Beton}

Kuat tekan beton mengidentifi-kasikan mutu dari sebuah struktur. Semakin tinggi tingkat kekuatan struktur yang di-kehendaki, semakin tinggi pula mutu beton yang dihasilkan. Pengujian kuat tekan beton paling penting dari kuat yang lainnya seperti lentur, tarik, lekatan dapat diperkirakan dari uji kuat tekan beton. Bentuk benda uji dapat berupa kubus, silinder dan prisma. Pemilihan bentuk spesimen ini akan berpe-ngaruh terhadap hasil pengukuran karena pola keruntuhan masing-masing bentuk berbeda.

\section{Kuat Tarik Belah Beton}

Kuat tarik belah $\left(\mathrm{f}_{\mathrm{ct}}\right)$ adalah kuat tarik beton yang ditentukan berdasarkan kuat tekan-belah silinder beton yang ditekan pada sisi panjangnya (Aji, 2007:12).

Berdasarkan SNI 03-2491-2002, tegangan tarik tidak langsung, dihitung dengan rumus: $f c t=\frac{2 P}{\pi l d} \quad$ dimana :

$f c t$ adalah kuat tarik beton (MPa). 
$P$ adalah beban hancur uji maksimum $(\mathrm{N})$ ditunjukkan mesin ujitekan. $l$ adalah panjang benda uji (mm). $d$ adalah diameter benda uji (mm).

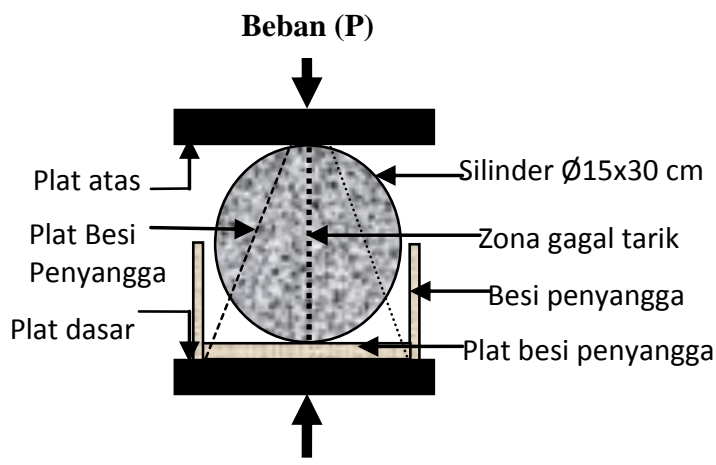

Gambar 2.5. Uji kuat tarik belah beton

\section{METODE PENELITIAN}

\section{Tempat dan Waktu Penelitian}

Penelitian ini dilakukan di laboratorium bahan bangunan dan beton Politeknik Negeri Malang, dan pelaksaannya dimulai pada tanggal 29 Juli sampai 30 Agustus 2014

\section{Bahan dan Peralatan}

Tabel bahan-bahan yang digunakan dalam seluruh pengujian

\begin{tabular}{|l|l|l|}
\hline 1 & Semen & $\begin{array}{l}\text { Semen PPC tipe 1 produksi PT. } \\
\text { Semen Gersik. }\end{array}$ \\
\hline 2 & $\begin{array}{l}\text { Agregat } \\
\text { halus }\end{array}$ & $\begin{array}{l}\text { Pasir Lumajang: BJ 2,778 } \\
\text { gram/cm }{ }^{3} \text { absorpsi 5,263 \%, } \\
\text { kadar air 7,7\%, analisa saringan } \\
\text { zona 1, dalam (Safrin Z. dan } \\
\text { Rahmat Arif J. : 2007). Ukuran } \\
\text { maksimum 5 mm. }\end{array}$ \\
\hline 3 & $\begin{array}{l}\text { Agregat } \\
\text { kasar }\end{array}$ & $\begin{array}{l}\text { Berupa kerikil atau batu yang } \\
\text { dipecah dengan mesin, ukuran } \\
\text { maksimum 40 mm yang diambil } \\
\text { dari Sungai Brantas Kabupten } \\
\text { Malang dan pegunungan di Desa } \\
\text { Beji Kecamatan Junrejo Kota } \\
\text { Batu. }\end{array}$ \\
\hline 4 & Air & Air dari PDAM Kodya Malang. \\
\hline
\end{tabular}

Peralatan dan bahan yang dipakai untuk setiap pengujian antara lain:

a. Satu set ayakan standar ASTM.

b. Satu set alat menguji berat volume agregat

c. Satu unit mesin pencampur adukan beton, kapasitas $0,84 \mathrm{~m}^{3}$

d. Satu set alat untuk menentukan slamp

e. Alat penggetar (Vibrator)

f. Cetakan silinder beton normal: $\phi 15 \mathrm{~cm}, \mathrm{~h}=30 \mathrm{~cm}$

g. Cetakan kubus dengan sisi 15 x $15 \mathrm{~cm}$ x $15 \mathrm{~cm}$.

h. Mesin uji tekan, berkapasitas $500 \mathrm{kN}$. 


\section{Rancangan penelitian}

Penelitian ini termasuk jenis pe-nelitian kuantitatif yang menggunakan perbandingan kualitas benda uji beton dengan agregat kasar dari mesin pemecah yang berasal dari Sungai Brantas Kabupaten Malang dan pegunungan di desa Beji Kecamatan Junrejo Kota Batu. Jumlah benda uji kuat tekan beton 10 buah dan kuat tarik belah beton 10 buah. secara lengkap pada

\section{Pengamatan}

Pada penelitian terapan ini yang perlu diteliti adalah kualitas agregat kasar, uji kuat tekan dan uji kuat tarik belah beton. Membandingkan antara kualitas agregat kasar yang berasal dari Sungai Brantas Kabupaten Malang dan yang berasal dari pegunugan di Desa Beji Kec. Junrejo Kota Batu. Mutu beton yang digunakan adalah fc' $30 \mathrm{MPa}$ (K300). Pengamatan data uji kuat tekan dan kuat tarik belah beton diambil pada usia 7 hari yang di konversi pada umur 28 hari.

\section{Prosedur Penelitian}

Tahapan pelaksanaan eksperimen ini dibagi menjadi 2 jenis pengujian, pertama yaitu pra pengujian untuk proporsi kekuatan beton yang diharapkan dan yang kedua yaitupengujian untuk mengamati kelayakan mutu benda uji beton.

\begin{tabular}{|c|c|c|}
\hline $\begin{array}{c}\mathbf{N} \\
\mathbf{0}\end{array}$ & Jenis Tahapan Pengujian & Acuan \\
\hline \multicolumn{3}{|c|}{ Tahapan Pra Pengujian } \\
\hline 1 & $\begin{array}{l}\text { Pemeriksaan berat satuan/ isi/ } \\
\text { volume agregat kasar }\end{array}$ & $\begin{array}{l}\text { SNI 03- } \\
4804-1998\end{array}$ \\
\hline 2 & Rongga udara agregat kasar & $\begin{array}{l}\text { SNI 03- } \\
4804-1998\end{array}$ \\
\hline 3 & $\begin{array}{l}\text { Analisa saringan/ gradasi } \\
\text { agregat kasar }\end{array}$ & $\begin{array}{l}\text { SNI 03- } \\
1968-1990 \\
\end{array}$ \\
\hline 4 & $\begin{array}{l}\text { Spesifik gravity agregat kasar } \\
\text { yaitu berat jenis curah (bulk) } \\
\text { dan berat jenis semu } \\
\text { (apparent) dan Penyerapan air } \\
\text { agregat kasar (absorpsi) }\end{array}$ & $\begin{array}{l}\text { SNI } \\
1969: 2008\end{array}$ \\
\hline 5 & Kadar air agregat kasar & $\begin{array}{l}\text { SNI 03- } \\
1971-1990\end{array}$ \\
\hline 6 & $\begin{array}{l}\text { Uji keausan agregat dengan } \\
\text { mesin Abrasi LosAngeles }\end{array}$ & $\begin{array}{l}\text { SNI-2417- } \\
2008\end{array}$ \\
\hline 7 & Uji Kekerasan agregat kasar & SK SNI \\
\hline \multicolumn{3}{|c|}{ Tahapan Pengujian } \\
\hline 8 & $\begin{array}{l}\text { Merancang campuran beton } \\
\text { normal ( mix design ) dengan } \\
\text { mutu beton fc' } 30 \mathrm{MPa}(\mathrm{K} 300 \\
\left.\mathrm{kg} / \mathrm{cm}^{2}\right)\end{array}$ & $\begin{array}{l}\text { SK.SNI.T- } \\
15-1990- \\
03\end{array}$ \\
\hline 9 & Tes slump beton & $\begin{array}{l}\text { SNI } \\
\text { 1972:2008 }\end{array}$ \\
\hline 10 & $\begin{array}{l}\text { Pembuatan dan perawatan } \\
\text { benda uji }\end{array}$ & $\begin{array}{l}\text { SNI 03- } \\
2493-1991\end{array}$ \\
\hline 11 & $\begin{array}{l}\text { Berat isi, volume produksi dan } \\
\text { kadar udara beton }\end{array}$ & $\begin{array}{l}\text { SNI } \\
1973: 2008\end{array}$ \\
\hline 12 & Kuat tekan beton & $\begin{array}{l}\text { SNI 03- } \\
1974-1990\end{array}$ \\
\hline 13 & Kuat tarik belah beton & $\begin{array}{l}\text { SNI- } \\
032491199 \\
1\end{array}$ \\
\hline
\end{tabular}




\section{Hipotesis Penelitian}

a. Diduga bahwa perbandingan pengujian kualitas agregat kasar berasal dari sungai lebih baik daripada agregat kasar dari gunung.

b. Diduga bahwa nilai kuat tekan beton yang menggunakan agregat kasar dari sungai lebih mendekati terhadap mutu beton fc' $30 \mathrm{MPa}$ (K300) daripada agregat kasar dari gunung.

c. Diduga bahwa nilai kuat tarik belah beton yang menggunakan agregat kasar dari sungai lebih baik daripada agregat kasar dari gunung.

\section{ANALISIS BAHAN DAN PERENCANAAN CAMPURAN}

\section{A. Pengujian Agregat Kasar}

Pengujian agregat kasar dimaksud-kan untuk mendapatkan bahan agregat kasar campuran beton yang memenuhi syarat, sehingga beton yang dihasikan nantinya sesuai dengan yang diharapkan di dalam kontrak kerja. Karena agregat kasar dalam campuran beton memberikan konstribusi yang besar terhadap campuran beton.

\begin{tabular}{|l|l|l|l|l|}
\hline \multirow{4}{*}{ Rencana penelitian } & \multicolumn{3}{|l|}{$\begin{array}{l}\text { Pengujiankuat tekan karakteristik } \\
\text { beton } \\
\text { (Kubus } 15^{3} \mathrm{~cm} \text { ) }\end{array}$} & $\begin{array}{l}\text { Pengujian } \\
\text { kuat tarik belah beton } \\
\text { (Silinder 15 x 30 cm) }\end{array}$ \\
\cline { 2 - 4 } & $\begin{array}{l}\text { Agregat kasar } \\
\text { dari Sungai } \\
\text { Brantas }\end{array}$ & $\begin{array}{l}\text { Agregat kasar } \\
\text { dari pegunungan } \\
\text { Desa Beji Batu }\end{array}$ & $\begin{array}{l}\text { Agregat kasar } \\
\text { dari Sungai } \\
\text { Brantas }\end{array}$ & $\begin{array}{l}\text { Agregat kasar dari } \\
\text { pegunungan Desa Beji } \\
\text { Batu }\end{array}$ \\
\hline Benda uji & 5 buah & 5 buah & 5 buah \\
\hline Perlakuan & $\begin{array}{l}\text { 1 hari dalam cetakan, direndam 6 hari dan } \\
\text { diuji pada usia 7 hari konversi28 hari }\end{array}$ \\
\hline
\end{tabular}

\section{Pemeriksaan Berat Isi dan Rongga Udara Agregat Kasar}

a. Tabel pengujian berat isi agregat kasar lepas/ cara sekop

\begin{tabular}{|l|l|l|l|}
\hline Pemeriksaan & Satuan & Batu Gunung & Batu Sungai \\
\hline Berat isi agregat kasar & $\mathrm{kg} / \mathrm{m}^{3}$ & 1.254 & 1.275 \\
\hline Berat isi kering permukaan & $\mathrm{Kg} / \mathrm{m}^{3}$ & 9,340 & 9,300 \\
\hline Kadar rongga udara & $\mathrm{Kg} / \mathrm{m}^{3}$ & 43,370 & 40,090 \\
\hline
\end{tabular}

b. Tabel data pengujian berat isi agregat kasar cara penusukan

\begin{tabular}{|l|l|l|l|}
\hline Pemeriksaan & Sat & Batu Gunung & Batu Sungai \\
\hline Berat isi agregat kasar & $\mathrm{kg} / \mathrm{m}^{3}$ & 1.338 & 1.352 \\
\hline Berat isi kering permukaan & $\mathrm{Kg} / \mathrm{m}^{3}$ & 9,970 & 9,860 \\
\hline Kadar rongga udara & $\mathrm{Kg} / \mathrm{m}^{3}$ & 43,360 & 40,080 \\
\hline
\end{tabular}

c. Tabel data pengujian berat isi agregat kasar cara penggoyangan/ ketuk

\begin{tabular}{|l|c|c|c|}
\hline \multicolumn{1}{|c|}{ Pemeriksaan } & Sat & Batu Gunung & Batu Sungai \\
\hline Berat isi agregat kasar & $\mathrm{kg} / \mathrm{m}^{3}$ & 1.324 & 1.415 \\
\hline Berat isi kering permukaan & $\mathrm{Kg} / \mathrm{m}^{3}$ & 9,870 & 10,330 \\
\hline Kadar rongga udara & $\mathrm{Kg} / \mathrm{m}^{3}$ & 43,360 & 40,080 \\
\hline
\end{tabular}

Dari ketiga pengujian dengan cara lepas dan cara penggoyangan berat isi dan rongga udara agregat gunung lebih besar daripada agregat sungai. Hal ini disebabkan oleh agregat yang berasal dari batu gunung lebih mudah pecah kemudian memperpadat isi, sehingga berat isi menjadi lebih besar. 


\section{Analisis Saringan Agregat Kasar}

- Jumlah presentase sisa terbesar pada ayakan 19,20 mm untuk agregat gunung tertahan $89,61 \%$ dan untuk agregat sungai tertahan $77,46 \%$.

- Modulus kehalusan agregat gunung 7,89 lebih tinggi daripada agregat sungai 7,74. Keduanya sesuai standar modulus kehalusan 5 sampai 8.

- Sesuai tabel dan grafik persentase tembus kumulatif pada masing-masing lubang ayakan $100 \%$ semuanya tembus ayakan $38,1 \mathrm{~mm}$ sedangkan yang tembus ayakan 19,20 mm untuk batu gunung $10,39 \%$ dan untuk agregat sungai $22,54 \%$.

\section{GRADASI MATERIAL AGREGAT KASAR CAMPURAN}

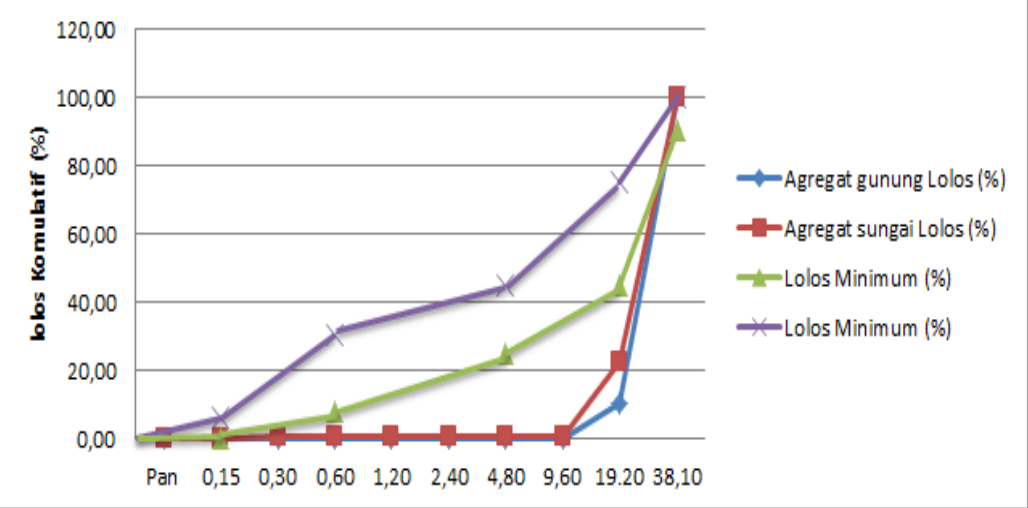

Gambar. Grafik pengujian gradasi agregat gunung dan sungai

\section{Pemeriksaan BJ Agregat Kasar}

Laporan hasil perhitungan dari dua pengujian berat jenis agregat kasar dari batu gunung tidak memenuhi syarat karena berat jenis kering permukaan jenuh agregat kasar sebesar $2440 \mathrm{~kg} / \mathrm{m} 3$ berada di bawah $2500-3000 \mathrm{~kg} / \mathrm{m}^{3}$. Sedangkan berat jenis agregat kasar dari batu sungai $2590 \mathrm{~kg} / \mathrm{m}^{3}$ memenuhi syarat karena berada diantara $2500-3000 \mathrm{~kg} / \mathrm{m}^{3}$. Jadi untuk beton yang menggunakan agregat kasar dari batu gunung perlu koreksi proporsi campuran.

\section{Penyerapan Air Agregat Kasar}

Penyerapan agregat kasar dari batu gunung 4,99\%, ini lebih besar dari agregat kasar dari batu sungai $2,77 \%$. Jadi lebih baik agregat kasar dari batu sungai karena penyerapannya lebih kecil.

\section{Pemeriksaan Kadar Air Agregat Kasar}

Kadar air rata-rata agregat kasar gunung $8,57 \%$ dan sungai 3,12\% sehingga kadar air agregat kasar dari gunung lebih besar daripada agregat kasar dari sungai.

\section{Pemeriksaan Kekerasan Agregat Kasar}

Hasil pengujian kekerasan agregat kasar yang berasal dari batu gunung nilai kehancurannya $33,25 \%$, dinyatakan tidak layak karena kehancurannya $>14 \%$. Sedangkan dari batu sungai/ kali nilai kehancurannya sebesar 10,02\%, dinyatakan layak untuk material mutu beton fc' $30 \mathrm{MPa}(\mathrm{K} 300)$ karena kehancuran $<14 \%$. 


\section{HASIL DAN PEMBAHASAN}

Kebutuhan Bahan Beton Penelitian untuk Kubus dan Silinder

Berdasar SNI 7394:2008. Untuk membuat $1 \mathrm{~m}^{3}$ beton mutu fc' $30 \mathrm{MPa}$ (K300), FAS: 0,52, slump $6 \pm 2 \mathrm{~cm}$ dan kebutuhan: Semen $=413 \mathrm{~kg} / \mathrm{m}^{3}:$ Pasir $=681 \mathrm{~kg} / \mathrm{m}^{3}:$ Kerikil $=$ $1021 \mathrm{~kg} / \mathrm{m}^{3}$, Air $=215 \mathrm{liter} / \mathrm{m}^{3}$. Sehingga kebutuhan campuran pada:

1. Volume untuk 10 buah kubus ditambah 2 cadangan jadi 12 buah:

- 6 buah(Agregat kasar dari Sungai Brantas Kab. Malang).

- 6 buah(Agregat kasar dari Pegunungan Desa Beji Kota Batu).

$\mathrm{V}_{\text {kubus }}=\mathrm{S} \times \mathrm{S} \times \mathrm{S}\left(\mathrm{m}^{3}\right)$ $=0,15 \mathrm{~m} \times 0,15 \mathrm{~m} \times 0,15 \mathrm{~m} \times 6 \mathrm{bh}=0,02025 \mathrm{~m}^{3}$

Semen $=0,02025 \mathrm{~m}^{3} \times 413 \mathrm{~kg} / \mathrm{m}^{3}=8,36 \mathrm{~kg} / \mathrm{m}^{3}$

Pasir $=0,02025 \mathrm{~m}^{3} \times 681 \mathrm{~kg} / \mathrm{m}^{3}=13,79 \mathrm{~kg} / \mathrm{m}^{3}$

Kerikil $=0,02025 \mathrm{~m}^{3} \times 1021 \mathrm{~kg} / \mathrm{m}^{3}=20,67 \mathrm{~kg} / \mathrm{m}^{3}$

Air $=0,02025 \mathrm{~m}^{3} \times 215$ liter $/ \mathrm{m}^{3}=4,35$ liter $/ \mathrm{m}^{3}=4350 \mathrm{cc} / \mathrm{m}^{3}$

2. Volume untuk 10 buah silinder ditambah 2 cadangan jadi 12 buah:

- 6 buah(Agregat kasar dari Sungai Brantas Kab. Malang).

- 6 buah(Agregat kasar dari Pegunungan Desa Beji Batu).

$\mathrm{V}_{\text {silinder }}=\pi \times \mathrm{r}^{2} \mathrm{x} \mathrm{t}$

$$
=\left(3,14 \times 0,075^{2} \mathrm{~m} \times 0,3 \mathrm{~m}\right) \times 6 \mathrm{bh}=0,032 \mathrm{~m}^{3}
$$

Semen $=0,0318 \mathrm{~m}^{3} \times 413 \mathrm{~kg} / \mathrm{m}^{3}=13,13 \mathrm{~kg} / \mathrm{m}^{3}$

Pasir $=0,0318 \mathrm{~m}^{3} \times 681 \mathrm{~kg} / \mathrm{m}^{3}=21,66 \mathrm{~kg} / \mathrm{m}^{3}$

Kerikil $=0,0318 \mathrm{~m}^{3} \times 1021 \mathrm{~kg} / \mathrm{m}^{3}=32,47 \mathrm{~kg} / \mathrm{m}^{3}$

Air $=0,0318 \mathrm{~m}^{3} \times 215$ liter $/ \mathrm{m}^{3}=6,84$ liter $/ \mathrm{m}^{3}=6840 \mathrm{cc} / \mathrm{m}^{3}$

\section{Pengujian Slump Beton}

Hasil pengujian slump yang meng-gunakan batu gunung sudah terlihat homo-gen dan encer pada slump 4,12 cm dan menyisakan 0,7 liter. Sedangkan yang meng-gunakan batu sungai/ kali dengan slump $6,83 \mathrm{~cm}$ yang lebih tinggi dari batu gunung tidak menyisakan air.

Nilai keduanya memenuhi standar slump untuk rencana balok, kolom struktur dan dinding beton antara $2,54-10,16 \mathrm{~cm}$.

\section{Hasil Pemeriksaan Kuat Tekan Beton}

Berikut ini tabel data pengujian Kuat Tekan beton kubus menggunakan agregat kasar dari gunung rencana fc' $30 \mathrm{MPa}(\mathrm{K} 300)$

\begin{tabular}{|c|c|c|c|c|c|}
\hline \multirow{3}{*}{ No } & \multirow{2}{*}{ Berat } & \multirow{2}{*}{\multicolumn{2}{|c|}{ Beban Tekan }} & \multicolumn{2}{|c|}{ Kekuatan Tekan } \\
\hline & & & & Kubus & Silinder \\
\hline & $(\mathrm{kg})$ & \multicolumn{2}{|l|}{$(\mathrm{KN})$} & $\left(\mathrm{kg} / \mathrm{cm}^{2}\right)$ & $\left(\mathrm{kg} / \mathrm{cm}^{2}\right)$ \\
\hline 1 & 8,0 & \multicolumn{2}{|l|}{855} & 584,62 & 704,36 \\
\hline 2 & 7,7 & \multicolumn{2}{|l|}{935} & 639,32 & 770,26 \\
\hline 3 & 7,9 & \multicolumn{2}{|l|}{950} & 649,57 & 782,62 \\
\hline 4 & 7,8 & \multicolumn{2}{|l|}{835} & 570,94 & 687,88 \\
\hline \multirow[t]{2}{*}{5} & 7,7 & \multicolumn{2}{|l|}{925} & 632,48 & 762,02 \\
\hline & 7,82 & \multicolumn{2}{|l|}{900} & 615,38 & 741,43 \\
\hline No. & $\mathrm{xi}-\overline{\bar{x}}$ & $(\mathrm{xi}-\bar{x})^{2}$ & \multicolumn{2}{|c|}{$S D=\sqrt{\frac{\sum_{i-1}^{n}(\mathrm{xi}-\bar{x})^{2}}{n-1}}$} & $K V=\frac{S D}{\bar{X}} \times 100 \%$ \\
\hline 1 & $-30,77$ & 946,75 & \multirow{3}{*}{\multicolumn{2}{|c|}{$S D=\sqrt{\frac{\sum_{i=1}^{5}(4955,80)}{5-1}}$}} & \multirow{3}{*}{$K V=\frac{78,70}{615,38} \times 100 \%$} \\
\hline 2 & 23,93 & 572,72 & & & \\
\hline 3 & 34,19 & 1168,82 & & & \\
\hline
\end{tabular}




\begin{tabular}{|c|c|c|c|c|}
\hline 4 & $-44,44$ & 1975,31 & \multicolumn{2}{|c|}{} \\
\hline 5 & 17,09 & 292,21 & & \multicolumn{2}{|c|}{12,79} \\
\hline & Jumlah & 4955,80 & 78,70 & \\
\hline
\end{tabular}

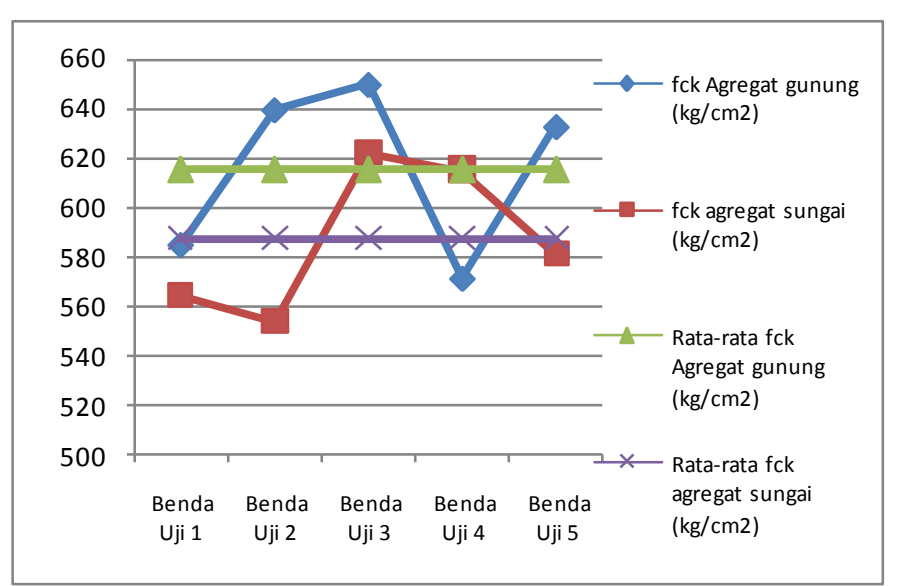

Gambar. Grafik kuat tekan beton dengan agregat gunung dan sungai

Hasil perhitungan kuat tekan rata-rata yang menggunakan agregat kasar dari gunung yaitu $615,38 \mathrm{~kg} / \mathrm{cm}^{2}$ masuk fc' $60 \mathrm{MPa}$ (K600) dan dari sungai yaitu $587,35 \mathrm{~kg} / \mathrm{cm}^{2}$ masuk fc' $50 \mathrm{MPa}$ (K500). Keduanya lebih besar dari rencana fc' $30 \mathrm{MPa}$ (K300). Agregat kasar dari gunung memiliki nilai kuat tekan beton lebih besar dibandingkan dari sungai, karena agregat kasar dari gunung walaupun dicuci dengan cara penyiraman air tetap berpasir sehingga mengisi rongga antar agregat kasar.

\section{Hasil Pemeriksaan Kuat Tarik Belah Beton}

$$
\text { Rumus: } f c t=\frac{2 P}{\pi l d}
$$

Berikut ini tabel data pengujian kekuatan tarik belah beton silinder menggunakan agregat kasar dari gunung

\begin{tabular}{|c|c|c|c|c|c|}
\hline \multirow{2}{*}{ No. } & \multirow{2}{*}{ Berat } & $\begin{array}{c}\text { Beban } \\
\text { Tekan }\end{array}$ & \multicolumn{3}{|c|}{ Kuat tarik belah } \\
\cline { 2 - 6 } & $(\mathrm{kg})$ & $(\mathrm{KN})$ & $\begin{array}{c}(\mathrm{MPa}) \\
7 \text { hari }\end{array}$ & $\begin{array}{c}(\mathrm{MPa}) \\
28 \text { hari }\end{array}$ & $\begin{array}{c}\mathrm{kg} / \mathrm{cm}^{2} \\
7 \text { hari }\end{array}$ \\
\hline 1 & 12,40 & 138,5 & 1,96 & 3,02 & 19,60 \\
\hline 2 & 12,26 & 175,0 & 2,48 & 3,81 & 24,77 \\
\hline 3 & 12,35 & 110,0 & 1,56 & 2,40 & 15,57 \\
\hline 4 & 12,40 & 131,0 & 1,85 & 2,85 & 18,54 \\
\hline 5 & 12,30 & 126,0 & 1,78 & 2,74 & 17,83 \\
\hline & 12,34 & 136,10 & 1,93 & 2,96 & 19,26 \\
\hline
\end{tabular}

Berikut ini tabel data pengujian kekuatan tarik belah beton silinder menggunakan agregat kasar dari sungai

\begin{tabular}{|c|c|c|c|c|c|}
\hline \multirow{2}{*}{ No. } & \multirow{2}{*}{ Berat } & $\begin{array}{c}\text { Beban } \\
\text { Tekan }\end{array}$ & \multicolumn{3}{|c|}{ Kuat tarik belah } \\
\cline { 2 - 6 } & $(\mathrm{kg})$ & $(\mathrm{KN})$ & $\begin{array}{c}(\mathrm{MPa}) \\
7 \text { hari }\end{array}$ & $\begin{array}{c}(\mathrm{MPa}) \\
28 \text { hari }\end{array}$ & $\begin{array}{c}\mathrm{kg} / \mathrm{cm}^{2} \\
7 \text { hari }\end{array}$ \\
\hline 1 & 12,60 & 178,0 & 2,52 & 3,88 & 25,19 \\
\hline 2 & 12,30 & 207,0 & 2,93 & 4,51 & 29,30 \\
\hline 3 & 12,60 & 113,5 & 1,61 & 2,47 & 16,07 \\
\hline
\end{tabular}




\begin{tabular}{|l|l|l|l|l|l|}
\hline 4 & 12,50 & 190,0 & 2,69 & 4,14 & 26,89 \\
\hline 5 & 12,50 & 126,0 & 1,78 & 2,74 & 17,83 \\
\hline & 12,50 & 162,9 & 2,31 & 3,55 & 23,06 \\
\hline
\end{tabular}

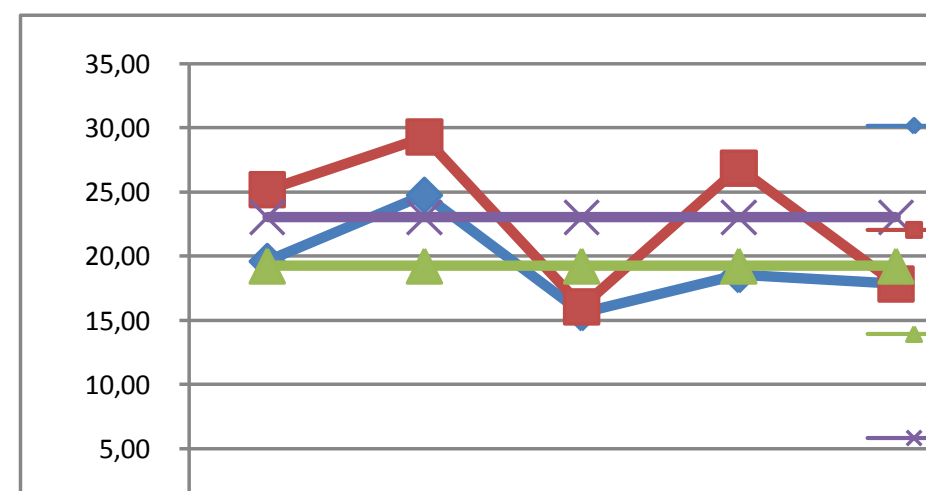

Gambar. Grafik uji kuat tarik belah beton dengan agregat gunung dan sungai

Hasil pengujian kuat tarik belah rata-rata umur 28 hari menggunakan agregat kasar dari gunung yaitu $29,6 \mathrm{~kg} / \mathrm{cm}^{2}$ atau $3,99 \%$ dari kuat tekan silinder $741,43 \mathrm{~kg} / \mathrm{cm}^{2}$ dan dari sungai yaitu $35,5 \mathrm{~kg} / \mathrm{cm}^{2}$ atau $5,02 \%$ dari kuat silinder $707,65 \mathrm{~kg} / \mathrm{cm}^{2}$. Sehingga persentase masing-masing kuat tarik belah beton kurang dari $10 \%$ terhadap kuat tekannya.

\section{KESIMPULAN DAN SARAN}

\section{Kesimpulan}

Berdasarkan hasil analisa dan pembahasan yang telah dilakukan, maka kesimpulan yang dapat diambil dari penelitian ini adalah sebagai berikut:

Hasil pengujian kualitas agregat kasar dari batu sungai lebih baik daripada batu gunung, ditinjau dari hasil uji berat jenis, penyerapan air, kadar air, keausan dan kekerasan. Karena batu sungai termasuk jenis batuan vulkanik yang lebih baik daripada batu gunung yang termasuk jenis batuan endapan. Hasil pemecahan agregat secara manual lebih baik daripada meng-gunakan mesin karena dilakukan sedikit demi sedikit dan pemilihan batu lebih teliti.

Nilai rata-rata kuat tekan beton keduanya lebih dari mix design fc' $30 \mathrm{MPa}(\mathrm{K} 300)$, kelas mutu beton untuk batu gunung masuk pada fc' $60 \mathrm{MPa}$ (K600) dan untuk batu sungai masuk pada kelas K500. Penyebab tingginya mutu beton melebihi rencana fc' $30 \mathrm{MPa}$ (K300) menjadi fc' $50 \mathrm{MPa}(\mathrm{K} 500)$ dan fc' $60 \mathrm{MPa}$ (K600) karena mix design yang digunakan adalah SNI untuk RAB dilapangan dan bukan mix design SNI untuk dilaboratorium yang secara teori sudah berbeda, pemecahan batu dilakukan manual sehingga lebih teliti dalam membentuk dan menyeleksi agregat kasar sesuai kebutuhan, juga karena nilai konversi umur beton dari umur 7 hari ke 28 hari serta penggunaan pasir yang terbaik dari zona 1 Kabupaten Lumajang. Hasil rata-rata kuat tekan beton yang menggunakan agregat kasar dari batu gunung yaitu $615,38 \mathrm{Kg} / \mathrm{cm}^{2}$ lebih tinggi dari batu sungai yaitu $587,35 \mathrm{~kg} / \mathrm{cm}^{2}$.

Nilai rata-rata kuat tarik belah beton menggunakan agregat kasar dari gunung yaitu 29,6 $\mathrm{kg} / \mathrm{cm}^{2}$ lebih rendah dibandingkan dari sungai yaitu $35,5 \mathrm{~kg} / \mathrm{cm}^{2}$. Jadi pada pengujian kuat tarik belah beton yang menggunakan agregat kasar dari sungai lebih baik daripada dari gunung. Hasil perbandingan kuat tarik belah beton sama-sama kurang dari 10\% terhadap nilai kuat tekannya.

\section{Saran}


Demi hasil penelitian yang lebih akurat serta untuk mengembangkan pe-nelitian lebih lanjut disarankan untuk melakukan penelitian dengan memperhatikan hal-hal sebagai berikut:

Jika kualitas agregat kasar di suatu daerah belum diketahui, hendaknya di- lakukan pengujian kualitas agregat kasar dahulu untuk keperluan mix design, sehingga takaran campuran beton sesuai kebutuhan di lapangan.

Agar nilai deviasi standar pengujian kuat tekan beton lebih akurat, sebaiknya pada setiap jenis pengujian yang sama menggunakan jumlah sampel benda uji minimum 30 buah dengan proporsi campuran yang sama.

Supaya nilai uji kuat tarik belah beton juga lebih akurat, sebaiknya pada pengujian yang sama juga menggunakan jumlah sampel benda uji minimum 30 buah dengan proporsi campuran yang sama sesuai standar mix design SNI. Untuk mening-katkan nilai kuat tarik beton sebaiknya dicari nilai minimal kuat tarik belah beton diatas $10 \%$ dari kuat tekannya.

\section{DAFTAR PUSTAKA}

Aji, Pujo dan Purwono, Rachmat. 2010. Pengendalian mutu beton sesuai SNI, ACI dan ASTM. Surabaya: ITS Press.

Annonymous. http://kamusbahasaindonesia.org. Diakses tanggal 2 Februari 2012.

Annonymous.http://www.ilmusipil.com/tabel-konversi-beton-3-sampai-28-hari Diakses tanggal 2 Februari 2012.

Annonymous. SK SNI T-15-03. 1990. Tata cara rancangan campuran beton normal. Jakarta:Departemen Pekerjaan Umum.

Annonymous. SK SNI T-15-03. 1991. Tata cara perhitungan struktur beton untuk bangunan gedung. Bandung: Yayasan LPMB.

Annonymous. SNI-03-1968. 1990. Metode pengujian tentang analisis saringan agregat halus dan kasar.Jakarta:Departemen Pekerjaan Umum.

Annonymous. SNI 03-1971. 1990. Metode pengujian kadar air agregat.Jakarta:Departemen Pekerjaan Umum.

Annonymous. SNI 03-2458. 1991. Metode pengambilan contoh untuk beton segar.Jakarta:Departemen Pekerjaan Umum.

Annonymous. SNI 03-2491. 2002. Metode pengujian kuat tarik belah beton. Jakarta: Badan Standarisasi Nasional.

Annonymous. SNI-03-2834. 1993. Tata cara pembuatan rencana campuran beton normal. Pusjatan-Balitbang PU.

Annonymous. SNI 03-4804. 1998. Metode pengujian bobot isi dan rongga udara dalam agregat. Jakarta:Departemen Pekerjaan Umum.

Annonymous. SNI 15-2049. 2004. Semen portland. Jakarta: Badan Standarisasi Nasional.

Annonymous. SNI 1972. 2008. Cara uji slump beton. Jakarta: Badan Standarisasi Nasional.

Annonymous. SNI 1973. 2008. Cara uji berat isi, volume produksi campuran dan kadar udara beton. Jakarta: Badan Standarisasi Nasional.

Annonymous. SNI 2417. 2008. Cara uji keausan agregat denganmesin abrasi Los Angeles. Jakarta: Badan Standarisasi Nasional.

Annonymous. SNI 7394. 2008. Tata cara perhitungan harga satuan pekerjaan betonuntuk konstruksi bangunan gedung dan perumahan. Jakarta: Badan Standarisasi Nasional.

Annonymous. SNIT-15-03. 1990. Tata cara penilaian dan penerimaan beton normal selama pelaksanaan bangunan. Departemen Pemukiman dan Prasarana Wilayah. 
Basyar Bustan,Abdul Fattah,Abdul Nabi.2003. Kuat Tekan Beton Menggunakan Agregat Kasar Bergradasi/Berukuran Seragam, Jurnal Penelitian Teknik Sipil(INTENSIP), Tahun 2,Nomor 2, Oktober 2003, Politeknik Negeri Ujung Pandang-Makassar.

Frick, Heinz dan Koesmartadi, Ch. 1999. Ilmu bahan bangunan eksploitasi, pembuatan, penggunaan dan pembuangan. Yogyakarta: Penerbit Kanisius.

Gideon Kusuma. 1993. Pedoman Pengerjaan Beton, Erlangga, Jakarta.

Tri Mulyono. 2005. Teknologi beton. Yogyakarta: Penerbit Andi.

Nasution, Amriyansyah. 2009. Analisis dan desain struktur beton bertulang. Bandung: Penerbit ITB.

Nawy, G Edward., Tavid dan Kusuma, Benny. 2010.Beton bertulangsebuah pendekatan mendasar. Surabaya:ITS Press.

Nugraha, Paul dan Antoni. 2007. Teknologi beton dari material, pembuatan, ke beton kinerja tinggi. Yogyakarta: Penerbit Andi.

Nurlina, Siti. 2008.Struktur beton. Malang:Bargie Media.

Reda Taha M.M.\& Shrive N.G. 2001. Fracture of Civil Engineering Materials ENCI 617, Fracture of Concrete- Lecture Notes.

Supartono F.X. 2001. Beton, Bahan Dasar dan Kekuatannya, Trend Teknik Sipil Era Milenium Baru, Yayasan John Hi-Tech Idetama , Jakarta,

Suseno, Hendro.2010. Bahan bangunan untuk teknik sipil. Malang: Bargie Media.

Tata Surdia dan Shinroku Saito. 2000. Pengetahuan Bahan Teknik, Pradnya Paramita, Jakarta. Wuryati S. dan Candra R. 2001. Teknologi Beton, Kanisius, Yogyakarta.

Zuraidah,Safrindan Jatmiko, Rahmat Arif. 2007. Pengaruh penggunaan limbah pecahan batu marmer sebagaialternatif pengganti agregat kasar pada kekuatan beton. Surabaya: Universitas Dr. Soetomo. 